Journal of Applied Pharmaceutical Science Vol. 5 (05), pp. 045-048, May, 2015

Available online at http://www.japsonline.com

DOI: $10.7324 / \mathrm{JAPS} .2015 .50508$

ISSN 2231-3354 (cc) BY-NC-SA

\title{
Cytotoxic effect of A nnona muricata Linn leaves extract on Capan-1 cells
}

\author{
Mohamad Norisham Mohamad Rosdi ${ }^{1}$, Nik Nurul Najihah Nik Mat Daud ${ }^{1}$, Razauden Mohamed Zulkifli ${ }^{2}$, Harisun \\ Ya'akob $^{4}$ \\ ${ }^{1}$ Department of Bioprocess Engineering, Faculty of Chemical Engineering, Universiti Teknologi Malaysia, 81310, Skudai, Johor, Malaysia. ${ }^{2}$ Department of \\ Biosciences and Health Sciences, ${ }^{3}$ Faculty of Bioscience and Medical Engineering, Universiti Teknologi Malaysia, 81310, Skudai, Johor, Malaysia. \\ ${ }^{4}$ Institute of Bioproduct Development, Universiti Teknologi Malaysia 81310, Skudai, Johor, Malaysia.
}

\author{
ARTICLE INFO \\ Article history: \\ Received on: 24/02/2015 \\ Revised on: 16/03/2015 \\ Accepted on: 04/04/2015 \\ Available online: 27/05/2015 \\ Key words: \\ Annona muricata Linn, \\ Graviola, MTT, Pancreatic \\ cancer, Capan-1, Maceration.
}

\begin{abstract}
Annona muricata Linn has been reported to contain valuable bioactive compounds known as Annonaceous acetogenins. Theselong chain fatty acids were widely discussed for its potential in promoting anticancer and antiproliferative activity in various cancer cell lines. However, little study has been done on A. muricata effect in pancreatic cancer cells. In this study, the viability of Capan-1 after treatment with A. muricata extracts was determined by using 3-(4, 5-dimethylthiazol-2-yl)-2, 5-diphenyltetrazolium bromide (MTT) assay. The results displayed that only hexane and commercialized extract inhibited cell proliferation in a concentration-dependent manner with $\mathrm{IC}_{25}$ varied $\sim 7.8-8 \mu \mathrm{g} / \mathrm{ml}$ and $\sim 0.9-1.0 \mu \mathrm{g} / \mathrm{ml}$ respectively. The data demonstrate that $A$. muricata hexane and commercialized extracts induced mild cytotoxicity in pancreatic cancer cells (Capan-1).
\end{abstract}

\section{INTRODUCTION}

Pancreatic cancer remains as one of the most aggressive cancer in the world, with 280000 and 338000 new cases diagnosed in 2008 and 2012 respectively (Ferlay et al., 2013, 2010). Although these numbers accounts for only $3 \%$ of all types of cancer, pancreatic cancer continues topping the chart as a top leading cause of cancer mortality and it also has recorded the highest death rate compared to other cancers (Hidalgo, 2010; Siegel et al., 2012). This circumstance is reflected by the data reported by National Cancer Institute (NCI) indicating that from 2001 until 2007, the dismal 5 year survivability for majority of the patients was $5.5 \%$ and this number has not varied for the last few decades despite immense efforts ("SEER Stat Fact Sheet: Pancreas," n.d.). In the recent decades, the cross application of different cancer treatments such as by integrating natural

\footnotetext{
* Corresponding Author

Harisun Ya'akob, Institute of Bioproduct Development, Faculty of Chemical Engineering, Universiti Teknologi Malaysia, 81310, Skudai, Johor, Malaysia.Mailid: harisun@ibd.utm.my
}

substances into the established chemotherapy is steadily gaining interest. Plant-derived natural substances have long been targeted to possess capability in controlling cancer cells progression. In fact, majority of the chemo-drug used in clinical today are originated from plants.

For example, Annona muricata or Graviola has been vastly postulated to own valuable natural products that purportedly play key role in promoting anticancer activity. A. muricata leaves have been subjected to investigation of numerous numbers of human diseases, including cancer (Taylor and Press, 2005). The highly sought effects are most probably induced by its major bioactive components known as annonaceous acetogenins (ACGs).

ACGs are widely reported for their anti-proliferative activity towards numerous numbers of cancer cell lines (Chang and Wu, 2001; Liaw et al., 2002; McLaughlin, 2008; Oberlies et al., 1995; Tormo et al., 2003). ACGs promotes cytotoxicity by affecting important process during cell metabolism, ATP generation and NADH oxidation. For example, Bullatacin, an ACG, has been reported to inhibit the proton pumping function of mitochondrial complex I resulting in short ATP supply (Degli Esposti et al., 1994). 
Besides inhibiting the complex I in the electron transport chain, ACGs also block the NADH oxidases on plasma membranes of cancer cells from functioning. The interruption in ATP production and NADH oxidation may contribute to the accumulation of superoxide and reactive oxygen species (ROS) that may encourage disastrous diseases.

In this study, cytotoxicity assay was carried out to provide preliminary evidence on the activity of $A$. muricata leaves extract fractions on pancreatic cancer cell line (Capan-1).

\section{MATERIALS AND METHODS}

\section{Plant material}

A. muricata Linn leaves were collected and deposited in the Herbarium, Biodiversity Unit, Institute of Bioscience, UPM, Serdang, Selangor, Malaysia. Then, the leaves were washed with distilled water and desiccated in the oven until the moisture content decreased to below $10 \%$. The dried leaves were ground.

\section{Preparation of the extract Maceration process}

Ground leaves were macerated in methanol at room temperature for $24 \mathrm{~h}$. The supernatant was filtered using Büchner funnel. Then, the filtrated extract was evaporated using rotary evaporator. The dried extract was dissolved in $10 \%$ methanol and sonicated for a few minutes.

The dissolved extract was mixed with hexane followed by chloroform in liquid-liquid portioning method. Therefore, three types of extract namely $10 \%$ methanol, hexane and chloroform were tested on cell line.

\section{Commercialized extract}

Graviola supplement capsules were purchased from Raintree (Carson City, NV). The capsules consisted of $100 \%$ pure Graviola leaf. The capsule contents were suspended in DMSO (100 $\mathrm{mg} / \mathrm{mL})$. After incubating for $5 \mathrm{~min}$, the suspension was centrifuged and the supernatant was filtered to remove any remaining particles.

\section{Total phenolic determination}

The total phenolic content of each sample was determined by Total Phenolic Content (TPC) assay using FolinCiocalteu method based on method described by Lim et al. (2006) with some modification. $1 \mathrm{~mL}$ of the extracted leaves or a standard solution of gallic acid $(0.02,0.04,0.06,0.08,0.10 \mathrm{mg} / \mathrm{mL})$ were mixed with $1 \mathrm{~mL}$ of Folin-Ciocalteu reagent (which was diluted with distilled water) and $1 \mathrm{~mL}$ of $1 \mathrm{~N}$ sodium carbonate in test tubes. The tubes were then vortexed and incubated in the dark for 60 minutes at room temperature. Thereafter, the absorbance was measured at $725 \mathrm{~nm}$ against a blank by using a UV/Vis Spectrophotometer Lambda 35.

Gallic acid standard solution was prepared by dissolving it in ethanol. Standard solution of gallic acid was freshly prepared and all the samples and readings were done in triplicate.

\section{Total flavonoid content determination}

The total flavonoid content was measured with an aluminium chloride colorimetric assay according to methodology described by Atanassova et al. (2011). $1 \mathrm{~mL}$ of extract or a standard solution of catechin $(0.05,0.10,0.25,0.50 \mathrm{mg} / \mathrm{mL})$ was added to a $10 \mathrm{~mL}$ volumetric flask and $0.3 \mathrm{~mL} 5 \%$ sodium nitrate $\left(\mathrm{NaNO}_{2}\right)$ was added to it. After 5 minutes, $0.3 \mathrm{~mL} 10 \%$ aluminium chloride $\left(\mathrm{AlCl}_{3}\right)$ was added.

At the sixth minute, $2 \mathrm{~mL}$ of $1 \mathrm{M} \mathrm{NaOH}$ was added and the total volume was sum up as $3.6 \mathrm{~mL}$. The solution was mixed well and the absorbance was measured against a blank at $510 \mathrm{~nm}$ with a UV/Vis Spectrophotometer Lambda 35. Catechin standard solution was freshly prepared by dissolving it in distilled water. All the samples and standard were done in triplicate.

\section{DPPH photometric assay}

Sample stock solutions $(1.0 \mathrm{mg} / \mathrm{mL})$ were diluted to final concentrations of $500,250,125,50,25,10$ and $5 \mu \mathrm{g} / \mathrm{mL}$, in DMSO. An amount of $100 \mu \mathrm{L}$ of a $0.04 \%$ DPPH DMSO solution was added to $100 \mu \mathrm{L}$ of sample solutions of different concentrations in 96-well plate, and allowed to react at room temperature for $30 \mathrm{~min}$. After that, the absorbance values were measured at $515 \mathrm{~nm}$ and converted into the percentage antioxidant activity using the following formula:

$\%$ of inhibition $=$

$\frac{\text { Absorbance }_{\text {control }}-\left(\text { Absorbance }_{\text {sample }}-\text { Absorbance }_{\text {blank }}\right) \times}{\text { Absorbance }_{\text {control }}}$

DMSO $(0.1 \mathrm{~mL})$ plus plant extract solution $(0.1 \mathrm{~mL})$ was used as a blank. DPPH solution $(0.1 \mathrm{~mL} ; 0.04 \%)$ plus DMSO $(0.1$ $\mathrm{mL}$ ) was used as a negative control. The positive controls were ascorbic acid.EC $\mathrm{E}_{50}$ values were calculated by linear regression of plots where the abscissa represented the concentration of tested plant extracts and the ordinate the average percent of antioxidant activity from three separate tests.

\section{Cell culture}

Pancreatic cancer cell line (Capan-1) was purchased from the American Type Culture Collection (ATCC). In this study, passage 3 cells were used. Cells were cultured in Iscove's Modified Dulbecco's medium (IMDM) supplemented with 20\% FBS and antibiotics $(100 \mu \mathrm{g} / \mathrm{mL}$ penicillin and $100 \mu \mathrm{g} / \mathrm{mL}$ streptomycin). The cells were maintained at $37{ }^{\circ} \mathrm{C}$ and $5 \% \mathrm{CO} 2$ in a humidified atmosphere.

\section{Cytotoxicity assay}

To determine the cytotoxicity of $A$. muricata extract on Capan-1 cells, $3 \times 10^{4}$ cells were seeded per well on a 96-well plate in IMDM supplemented with $20 \%$ FBS and antibiotics. After cells reach about $80-90 \%$ confluence, different ten-fold concentrations $(0,0.1,1,10,100 \mu \mathrm{g} / \mathrm{mL})$ of the extracts were added into triplicate wells. After $48 \mathrm{~h}$, solution containing thiazolyl blue tetrazolium bromide (MTT) reagent (Sigma Aldrich, St. Louis, MO) was added into each wells. After $3 \mathrm{~h}$ incubation at 
$37{ }^{\circ} \mathrm{C}$ in $5 \% \mathrm{CO} 2$ in humidified atmosphere, the media was replaced with $100 \mu \mathrm{L}$ of isopropanol and DMSO solution $(1: 1)$ and the corresponding cytotoxicity values were calculated $(\lambda=540$ $\mathrm{nm})$. The experiment was repeated at least three times.

\section{Statistical analysis}

All values were represented as mean \pm SEM of three different experiments. The Graphpad Prism 6 software was used to determine the statistical significance within the treatment replicates in each experiment. The test of significance was applied wherever necessary and values obtained as $\mathrm{p}<0.05$ were considered as statistically significant.

\section{RESULTS}

\section{Phenolic composition of $A$. muricata}

The results indicated that polyphenols content in the extracts is less varied between extracts. The concentration of polyphenols is slightly higher in $10 \%$ methanolic extract. While, the level of flavonoids in extracts varied with hexane showed significantly higher concentration of flavonoids.

Table 1: Phenolic composition of $A$. muricata extract

\begin{tabular}{|c|c|c|c|}
\hline Extract & $\begin{array}{l}\text { Polyphenols } \\
\text { (GAE)/g } \\
\text { material) }\end{array}$ & $\begin{array}{r}\text { (mg } \\
\text { dried }\end{array}$ & $\begin{array}{l}\text { Flavonoids } \\
(\mathrm{CE}) / \mathrm{g} \\
\text { material) }\end{array}$ \\
\hline Hexane & $35.76 \pm 0.000^{*}$ & & $966.39 \pm 0.001^{*}$ \\
\hline Chloroform & $54.53 \pm 0.001 *$ & & $681.09 \pm 0.001 *$ \\
\hline $10 \%$ Methanol & $67.54 \pm 0.000 *$ & & $64.86 \pm 0.001 *$ \\
\hline Commercialized extract & $8.342 \pm 0.001 *$ & & $17.5 \pm 0.001 *$ \\
\hline
\end{tabular}

Values are represented as mean \pm SEM, $\mathrm{n}=3$.*P $<0.0001$ compared among types of extracts. Statistical analysis was done using one-way ANOVA.

\section{DPPH scavenging activity}

The DPPH radical scavenging activity was recorded in termsof \% Inhibition as shown in Figure 1. It was observed from Figure 1 that $10 \%$ methanolic and commercialized extract have minimum DPPH scavenging activity (lesser than 50\%) and hexane extract has maximum DPPH scavenging activity (78.652 \pm $2.062 \%)$. Chloroform extract also showed significantly higher activity $(68.529 \pm 2.709 \%)$. The results obtained were statistically significant with $\mathrm{p}<0.05$.

\section{Graviola extract induces cytotoxicity of Capan-1 cells}

Pancreatic cancer cell line (Capan-1) was incubated for $48 \mathrm{~h}$ with different concentrations of $A$. muricata fractions namely $10 \%$ methanol, hexane commercialized extract and chloroform. The results from the MTT cytotoxicity assay demonstrated a progressive increase in cytotoxicity effect with the increase in the concentrations of the hexane and commercialized extract (Figure 2).

No cytotoxicity activity was recorded for $10 \%$ methanol and chloroform extract (data not shown). After $48 \mathrm{~h}$ of treatment, the resulting $\mathrm{IC}_{25}$ of hexane and commercialized extract on Capan1 cells was $7.8-8$ and $0.9-1.0 \mu \mathrm{g} / \mathrm{ml}$, respectively.

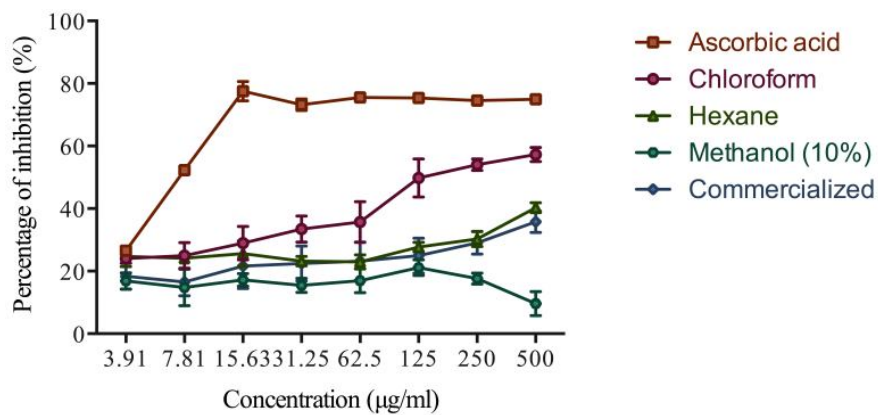

Fig. 1: Percentage of inhibition of extracts in DPPH assay. Values are represented as mean $\pm \operatorname{SEM},(n=3)$.

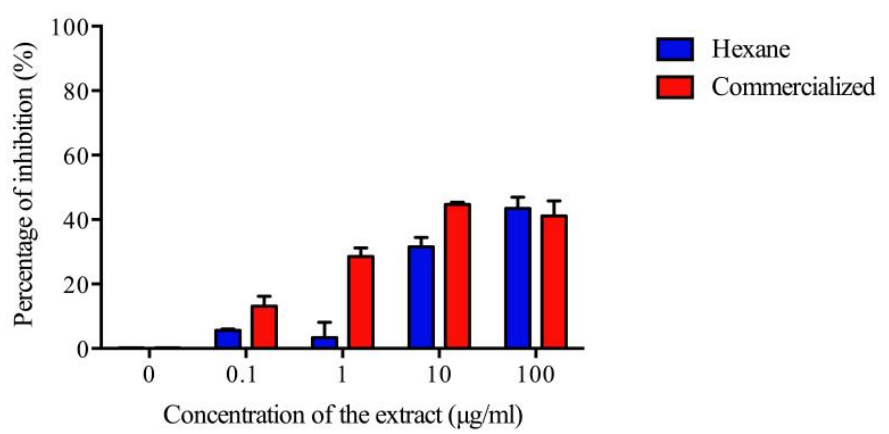

Fig. 2: Cytotoxicity effects of extracts on Capan-1 cells after $48 \mathrm{~h}$ treatment. Values are represented as mean \pm SEM, $(n=3)$. All values are statistically no difference.

\section{DISCUSSION}

A. muricata have the ability to treat wide-ranges of human diseases including cancer (Taylor and Press, 2005). There are numerous studies providing evidences to support this claim. Extracts from various parts of $A$. muricata were reported to display selective cytotoxic effects against various cancer cell lines such as pancreatic cancer, cervical cancer, lung cancer, and breast cancer (George and Kumar, 2012; Gomes de Melo et al., 2010; Paul et al., 2013; Torres et al., 2012). These cell proliferation assay results indicate the probability of $A$. muricata to own valuable type of phytochemicals that have significantly contribution to the antiproliferative effect of $A$. muricata.

Following the vast number of $A$. muricata preliminary anticancer research, it was discovered that the major bioactive components known as annonaceous acetogenins (ACGs) are the major contributor to anticancer effect. ACGs are derivatives of long chain (C35 to $\mathrm{C} 37$ ) fatty acids derived from the polyketide pathway. These fatty acids are found connected to a variable number of tetrahydrofuran (THF) or tetrahydropyran (THP) rings and a terminal lactone moiety (Russo et al., 2010). ACGs are fascinating compounds due to their well-recognized cytotoxicity against various types of cancer cell lines. This type of compound has gathered wide attention since it was first isolated. Since then, ACGs have become a potential candidate for anticancer drug.

However, only few studies were done to study the effect of this plant on pancreatic cancer line. Torres et al reported that the commercialized A. muricata leaves extract demonstrated 
mechanistic anticancer activity in pancreatic cancer cell lines (Torres et al., 2012). In another study, muricoveacin and murihexocin $\mathrm{C}$ isolated from the leaves for A. muricata displayed cytotoxicity against pancreatic carcinoma (PACA-2) (Kim et al., 1998).

Therefore, in this study, we used fractions prepared through methanolic maceration and liquid-liquid extraction. Nonpolar solvent such as methanol, hexane and chloroform are suitable to extract out ACGs from the leaves. As expected, hexane extract which has recorded highest flavonoids content inhibited cell proliferation in MTT assay.

The hexane extract can trigger cell death in Capan-1 cells either through necrosis or apoptosis. Torres et al reported that $A$. muricata promoted its activity through necrosis contrary to evidences which displayed that apoptosis is a mechanism of action (Torres et al., 2012). To further evaluate, flow cytometry analysis, gene expression and protein expression will be carried out in the future experiment.

\section{CONCLUSION}

In conclusion, we found that $A$. muricata leaves hexane fraction, which primarily contains flavonoids, reduced cell viability in human pancreatic cancer cells (Capan-1) in vitro. This hexane extract, therefore, has the potential of an anticancer agent. However, further study may still be necessary to elucidate the mechanism induced in Capan-1 cells by this extract.

\section{COMPETING INTERESTS}

The authors declared no potential conflicts of interest.

\section{REFERENCES}

Chang FR, Wu YC. Novel Cytotoxic Annonaceous Acetogenins from Annona muricata. J Nat Prod, 2011; 64:925-931.

Degli Esposti M, Ghelli A, Ratta M, Cortes D, Estornell E. Natural substances (acetogenins) from the family Annonaceae are powerful inhibitors of mitochondrial NADH dehydrogenase (Complex I). Biochem J,1994; 301:161-167.

Ferlay J, Shin, HR, Bray F, Forman D, Mathers C, Parkin DM. Estimates of worldwide burden of cancer in 2008: GLOBOCAN 2008. Int J Cancer, 2010; 127: 2893-2917.

Ferlay J, Soerjomataram I, Ervik M, Dikshit R, Eser S, Mathers C, Rebelo M, Oarkin DM, DForman D, Bray F. 2013. GLOBOCAN 2012 v1.0, Cancer Incidence and Mortality Worldwide: IARC CancerBase no. 11.

George V, Kumar D. Quantitative assessment of the relative antineoplastic potential of the n-butanolic leaf extract of Annona muricata Linn. in normal and immortalized human cell. Asian Pac J Cancer Prev, 2012; 13(2):699-704.
Gomes de Melo J, de Sousa Araújo TA, Thijan Nobre de Almeida e Castro V, Lyra de Vasconcelos Cabral D, do Desterro Rodrigues M, Carneiro do Nascimento S, Cavalcanti de Amorim EL, de Albuquerque UP. Antiproliferative activity, antioxidant capacity and tannin content in plants of semi-arid northeastern Brazil. Molecules, 2010; $15: 8534-42$

1617

Hidalgo M. Pancreatic Cancer. N Engl J Med, 2010; 362:1605-

Kim GS, Zeng L, Alali F, Rogers LL, Wu FE, Sastrodihardjo S, McLaughlin JL. Muricoreacin and murihexocin C, mono-tetrahydrofuran acetogenins, from the leaves of Annona muricata in honour of professor G. H. Neil Towers 75th birthday. Phytochemistry, 1998; 49:565-571.

Liaw CC, Chang FR, Lin CY, Chou CJ, Chiu HF, Wu MJ, Wu YC. New Cytotoxic Monotetrahydrofuran Annonaceous Acetogenins from Annona muricata. J Nat Prod, 2002; 65:470-475.

McLaughlin JL. Paw Paw and Cancer: Annonaceous Acetogenins from Discovery to Commercial Products. J Nat Prod, 2008; 71:1311-1321.

OberliesNH, Jones JL, Corbett TH, Fotopoulos SS, McLaughlin JL. Tumor cell growth inhibition by several Annonaceous acetogenins in an in vitro disk diffusion assay. Cancer Lett, 1995; 96:55-62.

Paul J, Gnanam R, Jayadeepa RM, Arul L. Anti cancer activity on Graviola, an exciting medicinal plant extract vs various cancer cell lines and a detailed computational study on its potent anti-cancerous leads. Curr Top Med Chem, 2013; 13:1666-73.

Russo M, Spagnuolo C, Tedesco I, Russo GL. Phytochemicals in Cancer Prevention and Therapy: Truth or Dare? Toxins, 2010; 2:517551.

SEER Stat Fact Sheet: Pancreas, n.d.

Siegel R, Naishadham D, Jemal A. Cancer statistics, 2012. CA Cancer J Clin, 2012; 62:10-29.

Taylor L, Press S. 2005. Technical Data Report for Graviola (Annona muricata). Austin, TX.

Tormo JR, Royo I, Gallardo T, Zafra-Polo MC, Hernandez P, Cortes D, Pelaez F. In vitro antitumor structure-activity relationships of threo/trans/threo mono-tetrahydrofuranic acetogenins: correlations with their inhibition of mitochondrial complex I. Oncol Res, 2003; 14:147-154.

Torres MP, Rachagani S, Purohit V, Pandey P, Joshi S, Moore ED, Johansson SL, Singh PK, Ganti AK, Batra SK. Graviola: A novel promising natural-derived drug that inhibits tumorigenicity and metastasis of pancreatic cancer cells in vitro and in vivo through altering cell metabolism. Cancer Lett, 2012; 323:29-40.

\section{How to cite this article:}

Mohamad Norisham Mohamad Rosdi, Nik Nurul Najihah Nik Mat Daud, Razauden Mohamed Zulkifli, Harisun Ya'akob. Annona muricata Linn leaves extract cytotoxicity effect on Capan-1 cells. J App Pharm Sci, 2015; 5 (05): 045-048 